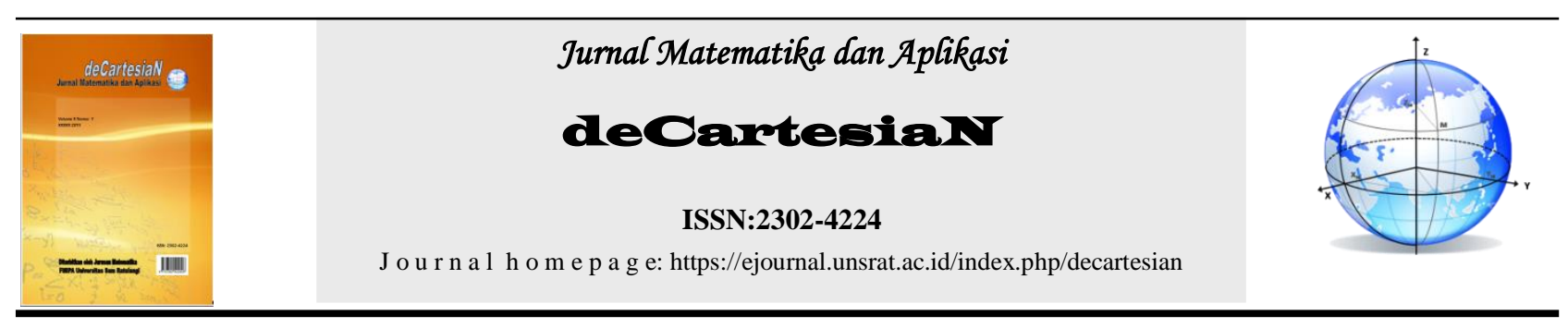

\title{
Sistem Pendukung Keputusan Pemilihan Karyawan Teladan di PT Aneka Tambang (ANTAM) Tbk Unit Bisnis Pertambangan Buli Menggunakan Metode Simple Additive weight (SAW)
}

\author{
Susanti Pareda ${ }^{1}$, Charles E. Mongi ${ }^{1}$, Chriestie E.J.C Montolalu ${ }^{1^{*}}$ \\ ${ }^{1}$ Jurusan Matematika-Fakultas Matematika dan Ilmu Pengetahuan Alam-Universitas Sam Ratulangi Manado,Indonesia \\ ${ }^{*}$ Corressponding author : chriestelly@unsrat.ac.id
}

\section{A B S T R A K}

Karyawan merupakan salah satu faktor penting dalam sebuah perusahaan karena dengan adanya karyawan yang memiliki standar kualifikasi perusahaan yang baik maka produktivitas perusahaan akan tetap terjaga dan semakin meningkat. Mengetahui pentingnya kualitas kinerja karyawan maka PT ANTAM Tbk melakukan pemilihan karyawan teladan untuk memacu semangat karyawan dalam meningkatkan dedikasi dan kinerja. Namun banyaknya karyawan yang akan dipilih menjadi kendala dalam pemilihan karyawan teladan, oleh sebab itu dibutuhkan suatu proses otomatisasi menggunakan teknologi untuk memberikan rekomendasi dalam pemilihan karyawan teladan. Tujuan penelitian ini adalah untuk merancang sebuah sistem pendukung keputusan dalam pemilihan karyawan teladan di PT ANTAM Tbk. Sistem pendukung keputusan adalah bagian dari sistem informasi berbasis komputer termasuk sistem berbasis pengetahuan atau manajemen pengetahuan yang dipakai untuk mendukung pengambilan sebuah keputusan dalam suatu organisasi atau perusahaan. Metode yang digunakan adalah metode SAW, perhitungan metode ini menggunakan hasil dari nilai terbesar yang akan dipilih sebagai alternatif terbaik, perhitungan akan sesuai apabila alternatif yang terpilih memenuhi kriteria yang telah ditentukan. Sistem pendukung keputusan pemilihan karyawan teladan ini dikembangkan dengan menggunakan bahasa pemrograman PHP (Pre-Hypertext Processor), serta Database MySQL sebagai database server. Hasil penelitian ini menunjukan karyawan A1o mendapat rangking 1 dengan persentase nilai $100 \%$.
\end{abstract}

\section{INFO ARTIKEL}

Diterima : 20 Desember 2018

Diterima setelah revisi : 19 januari 2019

Tersedia online: 31 Januari 2019

\section{Kata Kunci: \\ SPK \\ SAW \\ Karyawan Teladan \\ Basis Web}

\section{PENDAHULUAN}

Karyawan merupakan salah satu faktor penting dalam sebuah perusahaan atau instansi, karena dengan adanya karyawan yang memiliki standar kualifikasi perusahaan yang baik maka produktivitas perusahaan pasti akan tetap terjaga dan semakin meningkat. Oleh sebab itu sangat baik bagi suatu perusahaan memilih karyawan terbaik/teladan dan diberi penghargaan agar dapat meningkatkan kualitas karyawan dalam perusahaan tersebut.

PT Aneka Tambang Tbk atau yang biasa disebut dengan PT ANTAM Tbk merupakan perusahaan pertambangan yang sebagian besar sahamnya dimiliki oleh pemerintah Indonesia (65\%) dan masyarakat (35\%). Kegiatan PT ANTAM Tbk mencakup eksplorasi, penambangan, pengolahan serta pemasaran dari komoditas bijih nikel, feronikel, emas, perak, bauksit dan batubara [7].

Mengetahui pentingnya kualitas kinerja karyawan dalam perusahaan maka PT ANTAM Tbk melakukan pemilihan karyawan teladan untuk memacu semangat karyawan dalam meningkatkan dedikasi dan kinerja. Pemilihan karyawan teladan dilakukan secara periodik akan tetapi belum optimal dalam pelaksanaannya.
Proses penilaian kinerja karyawan merupakan proses yang rumit dan memerlukan pertimbanganpertimbangan yang cermat. PT ANTAM Tbk mendapat kendala dalam memutuskan karyawan yang akan diprioritaskan. Kendala yang dihadapi adalah manager SDM tidak menggunakan metode yang dapat menangani permasalahan prioritas dengan banyak kriteria. Selain itu seringkali SDM kesulitan memilih karyawan teladan dikarenakan banyaknya karyawan yang dinilai. Hal ini menjadi sebuah kekurangan untuk menentukan tepat atau tidaknya seorang terpilih sebagai karyawan teladan.

Untuk memperoleh informasi yang cepat dan akurat akan prestasi kinerja karyawan yang tepat (memenuhi kriteria yang diharapkan), dibutuhkan suatu proses otomatitasi dengan menggunakan teknologi. Oleh sebab itu kebutuhan sebuah sistem yang berbasis komputer dirasa sangat perlu guna memenuhi tuntutan akan kebutuhan informasi.

Dengan melihat kendala/permasalahan di atas penulis tertarik untuk melakukan analisis dalam pemilihan karyawan teladan di PT ANTAM Tbk dengan merancang sebuah sistem yang dapat membantu pimpinan perusahaan khususnya pembuat 
keputusan atau manajer HRD (Human Resources Departement).

Sistem yang dimaksud adalah Sistem pendukung keputusan (SPK). Sistem Pendukung

Keputusan merupakan sistem yang dapat membantu para pengambil keputusan dengan memanfaatkan komputer dalam pengambilan keputusan. Sistem yang dibuat menggunakan metode Simple Additive Weight (SAW). Metode SAW sering juga dikenal dengan istilah metode penjumlahan terbobot. Konsep dasar metode SAW adalah mencari penjumlahan terbobot dari rating kinerja pada setiap alternatif pada semua atribut [5]. Atribut disini dapat diartikan sebagai suatu kriteria atau ketetapan yang sudah dibuat oleh PT ANTAM Tbk untuk menentukan karyawan teladan. Kriteria yang ditetapkan yaitu lamanya masa kerja karyawan, Penilaian kinerja karyawan dan Penilaian Perilaku karyawan.

Berdasarkan uraian diatas sistem pendukung keputusan dengan menggunakan metode Simple Additive Weight (SAW) dapat membantu PT ANTAM Tbk dalam pemilihan karyawan teladan.

\section{TINJAUAN PUSTAKA}

\subsection{PT Aneka Tambang (ANTAM) Tbk}

PT Aneka Tambang Tbk atau yang biasa disebut PT ANTAM Tbk merupakan perusahaan pertambangan yang terdiversifikasi dan terintegrasi secara vertikal yang berorientasi ekspor. Melalui wilayah operasi yang tersebar di seluruh Indonesia yang kaya akan bahan mineral, kegiatan PT ANTAM Tbk mencakup eksplorasi, penambangan, pengolahan serta pemasaran dari komoditas bijih nikel, feronikel, emas, perak, bauksit dan batubara.

PT ANTAM Tbk didirikan sebagai Badan Usaha Milik Negara pada tahun 1968 melalui merjer beberapa perusahaan pertambangan nasional yang memproduksi komoditas tunggal. Untuk mendukung pendanaan proyek ekspansi feronikel, pada tahun 1997 PT ANTAM Tbk menawarkan 35\% sahamnya ke publik dan mencatatkannya di Bursa Efek Indonesia.

Tambang bijih nikel PT ANTAM Tbk berada di Pomalaa, Tanjung Buli dan Tapunopaka. Pomalaa yang berlokasi di Sulawesi Tenggara merupakan tambang nikel tertua sementara Tapunopaka yang merupakan tambang emas terbaru PT ANTAM Tbk juga berlokasi di Sulawesi Tenggara. Tambang nikel Tanjung Buli berlokasi di Maluku Utara.

\subsection{Sistem Pendukung Keputusan}

Sistem pendukung keputusan (SPK) adalah bagian dari sistem informasi berbasis komputer termasuk sistem berbasis pengetahuan atau manajemen pengetahuan yang dipakai untuk mendukung pengambilan sebuah keputusan dalam suatu organisasi atau perusahaan. Sistem pendukung keputusan dapat juga dikatakan sebagai sistem komputer dan informasi yang mengolah sebuah data menjadi informasi untuk digunakan oleh manajemen perusahaan/organisasi dalam menentukan sebuah keputusan [2].

Sistem pendukung keputusan adalah sebuah sistem berbasis komputer yang dapat melakukan bantuan dalam pengambilan keputusan untuk memecahkan suatu masalah dengan memangfaatkan data dan model tertentu [3]. Suatu sistem informasi berbasis komputer yang menghasilkan berbagai alternatif keputusan yang digunakan oleh manajemen dalam menangani berbagai permasalahan yang terstruktur ataupun tidak terstruktur dengan menggunakan data dan model, dapat pula disebut dengan sistem pendukung keputusan [8]. Decision support system (sistem pendukung keputusan) tidak menggantikan manusia, namun membantu manajemen dalam memecahkan masalah yang kompleks dengan integrasi berbagai sumber informasi, memberikan akses pengetahuan tentang kecerdasan yang relevan dan membantu dalam proses penataan dan pengoptimalan keputusan [9].

Sistem pendukung keputusan dirancang untuk mendukung seluruh tahap pengambilan keputusan mulai dari mengidentifikasi masalah, memilih data yang relevan dan menentukan pendekatan yang digunakan dalam proses pengambilan keputusan sampai mengevaluasi pemilihan altenatif-alternatif yang ada.

\subsection{Metode Simple Additive Weight (SAW)}

Metode Simple Additive Weight (SAW) sering juga dikenal dengan istilah metode penjumlahan terbobot. Konsep dasar metode Simple Additive Weight (SAW) adalah mencari penjumlahan terbobot dari rating kinerja pada setiap alternatif pada semua atribut [5]. Adapun langkah-langkah penghitungan metode Simple Additive Weight (SAW) adalah :

- Langkah 1: Membuat matriks keputusan

berdasarkan persamaan (1).

$$
\mathrm{Z}=m \times n
$$

Dimana:

$$
\begin{array}{ll}
\mathrm{Z} & =\text { Keputusan yang akan diambil } \\
m & =\text { Alternatif yang akan dipilih } \\
n & =\text { Kriteria }
\end{array}
$$

- Langkah 2: Memberikan nilai $X$ setiap alternatif (i) pada setiap kriteria (j) yang sudah ditentukan. Dimana $i=1,2, \ldots m$ dan $j=1,2, \ldots n$ pada matriks keputusan $\mathrm{Z}$ seperti persamaan (2).

$$
Z=\left[\begin{array}{ccc}
x_{11} x_{12} & \ldots & x_{1 j} \\
\vdots & & \vdots \\
x_{i j} x_{i 2} & \ldots & x_{i j}
\end{array}\right]
$$

- Langkah 3: Memberikan nilai bobot preferensi (W) oleh pengambilan keputusan untuk masing-masing kriteria yang sudah ditentukan seperti pada persamaan (3).

$$
W=\left[w_{1} w_{2} w_{3} \ldots w_{j}\right]
$$

- Langkah 4: Melakukan normalisasi matriks keputusan $\mathrm{Z}$ dengan cara menghitung nilai rating kinerja ternormalisasi $\left(R_{i j}\right)$ dan alternatif $A_{i}$ pada atribut $\mathrm{C}$ seperti pada persamaan (4).

$$
R_{i j}=\left\{\begin{array}{lc}
\frac{x_{i j}}{\operatorname{Max}\left(x_{i j}\right)} & \text { Jika } j \text { adalah atribut benefit } \\
\frac{\operatorname{Min}\left(x_{i j}\right)}{x_{i j}} & \text { Jika J adalah atribut cost }
\end{array}\right.
$$

Dimana :

$\mathrm{R}_{\mathrm{ij}} \quad=$ Rating kinerja ternormalisasi

$\mathrm{Max}_{\mathrm{ij}}=$ Nilai maksimum dari setiap baris dan kolom

$\operatorname{Min}_{\mathrm{ij}}=$ Nilai minimum dari setiap baris dan kolom

$\mathrm{X}_{\mathrm{ij}} \quad=$ Baris dan kolom dari matriks 
Dengan ketentuan :

1) Dikatakan atribut keuntungan apabila atribut yang memberikan keuntungan bagi pengambil keputusan, sedangkan atribut biaya merupakan atribut yang banyak memberikan pengeluaran jika nilainya semakin besar bagi pengambil keputusan.

2) Apabila berupa atribut keuntungan maka nilai (xij) dari setiap kolom atribut dibagi dengan nilai (Max xij) dari tiap kolom, sedangkan untuk atribut biaya, nilai (Min xij) dari tiap kolom atribut dibagi dengan nilai (xij) setiap kolom.

- Langkah 5: Hasil dari nilai rating kinerja ternormalisasi $\left(R_{i j}\right)$ membentuk matriks ternormalisasi (R) seperti pada persamaan (5).

$$
R=\left[\begin{array}{ccc}
r_{11} r_{12} & \ldots & r_{1 j} \\
\vdots & & \vdots \\
r_{i j} r_{i 2} & \ldots & r_{i j}
\end{array}\right]
$$

- Langkah 6: Melakukan proses perangkingan dengan cara mengalikan matriks ternormalisasi (R) dengan nilai bobot preferensi (W).

- Langkah 7: Menentukan nilai preferensi untuk setiap alternatif $\left(V_{i}\right)$ dengan cara menjumlahkan hasil kali antara matriks ternormalisasi (R) dengan nilai bobot preferensi (W) sesuai menggunakan persamaan (6).

$$
V_{i}=\sum_{j=1}^{n} W_{j} R_{i j}
$$

Dimana:

$$
\begin{array}{ll}
V_{i} & =\text { Nilai akhir alternatif } \\
W_{j} & =\text { Bobot yang telah ditentukan } \\
R_{i j} & =\text { Normalisasi Matriks }
\end{array}
$$

Nilai $V_{i}$ yang lebih besar mengindikasi bahwa alternative $A_{i}$ merupakan alternative terbaik.

\subsection{PHP (Pre-Hypertext Prepocessor)}

PHP adalah salah satu bahasa Server-side didesain khusus untuk aplikasi web. PHP dapat disisipkan diantara bahasa HTML (HyperText Markup Language) dan karena bahasa Server-side, maka bahasa PHP akan dieksekusi di server, sehingga yang dikirimkan ke browser adalah hasil jadi dalam bentuk HTML dan kode PHP tidak akan terlihat [9]. Fungsi PHP yang paling utama adalah untuk menghubungkan database dengan web [4].

\subsection{MySQL}

MySQL adalah sebuah program database server yang mampu menerima dan mengirimkan datanya dengan sangat cepat, multi user, serta menggunakan perintah standar SQL (Stucture Query Language) [6]. Sedangkan MySQL juga merupakan sistem manajemen database relasional. Database relasional menyimpan data dalam tabel-tabel terpisah. Tabel-tabel yang dihubungkan dengan relasi yang ditentukan, membuatnya bisa mengkombinasikan data dari beberapa tabel pada suatu permintaan. Data disimpan dalam database MySQL. Kemudian diolah dengan bantuan PHP. Proses shorting data dilakukan dengan query MySQL, PHP menghubungkan variabel dari form, Akses ke database, manipulasi string dan mengakses file sistem. Selanjutnya proses penyampaian data dilakukan dengan format HTML [1].

\subsection{XAMPP}

XAMPP merupakan tools yang menyediakan paket perangkat lunak kedalam satu buah paket. Dalam paketnya sudah terdapat Apache (webserver), MySQL (database), PHP (server side scripting), Perl, FTP server, phpAdmin dan berbagai pustaka bantu lainnya [1].

\section{METODE PENELITIAN}

\subsection{Waktu dan Tempat Penelitian}

Penelitian ini dilakukan pada bulan Juli 2018 di PT ANTAM Tbk Unit Bisnis Pertambangan Buli dan analisis data dilakukan di Laboratorium Komputer Dasar FMIPA UNSRAT.

\subsection{Variabel Penelitian}

Dalam penelitian ini Variabel yang digunakan adalah variabel alternatif dan variabel kriteria antara lain :

- Variabel Alternatif

A1,A2,...An = Karyawan PT ANTAM Tbk.

- Variabel Kriteria

$\mathrm{C} 1$ = Masa Kerja

$\mathrm{C} 2$ = Penilaian Kinerja

$\mathrm{C}_{3}=$ Penilaian Perilaku

\section{HASIL DAN PEMBAHASAN}

\subsection{Struktur Simple Additive weight (SAW)}

Berikut struktur Simple Additive Weight (SAW) yang akan digunakan dalam penelitian ini:

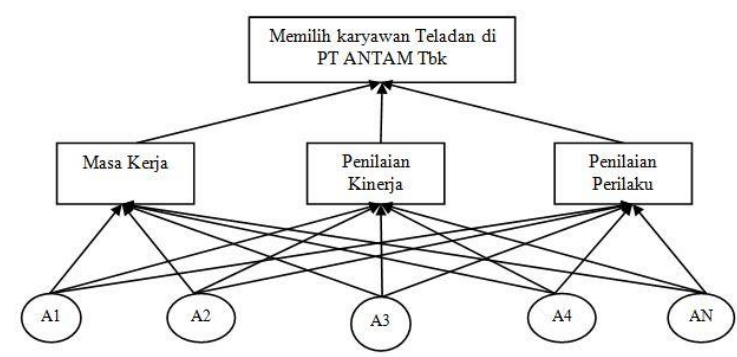

Gambar 1. Struktur Hirarki Alternatif penentuan karyawan teladan di PT ANTAM Tbk.

\subsection{Penentuan Kriteria Metode Simple Additive Weight}

Untuk melakukan pengambilan keputusan ini terdapat objek yang akan dibahas yaitu kriteria dan alternatif. Berikut adalah kriteria-kriteria yang dibutuhkan untuk mengukur dan menilai siapa yang akan terseleksi untuk mendapatkan penghargaan karyawan teladan, antara lain:

\section{a. Masa Kerja}

Indikator yang digunakan dalam penentuan karyawan teladan berdasarkan kriteria masa kerja dimana dinilai atau dilihat dari seberapa lama seorang karyawan sudah bekerja dalam perusahaan seperti yang ditunjukan didalam Tabel 1. 
Tabel 1. Kriteria Masa Kerja

\begin{tabular}{|c|c|c|}
\hline Kriteria & Range & Bobot \\
\hline \multirow{4}{*}{ Masa Kerja } & 0-1 Tahun & $\mathbf{1}$ \\
\cline { 2 - 3 } & 2 Tahun & 2 \\
\cline { 2 - 3 } & 3 Tahun & 3 \\
\cline { 2 - 3 } & 4 Tahun & 4 \\
\cline { 2 - 3 } & 5 Tahun & 5 \\
\hline
\end{tabular}

\section{b. Penilaian Kinerja}

Indikator yang digunakan dalam menentukan karyawan teladan berdasarkan penilaian kinerja adalah kemampuan karyawan dalam menyelesaikan pekerjaannya sesuai dengan target yang diberikan oleh perusahaan dengan pembobotan nilai seperti pada Tabel 2.

Tabel 2. Kriteria Penilaian Kinerja

\begin{tabular}{|c|c|c|}
\hline \multirow{2}{*}{ Kriteria } & Range & Bobot \\
\hline \multirow{4}{*}{$\begin{array}{c}\text { Penilaian } \\
\text { Kinerja }\end{array}$} & $<70$ (Tidak Baik) & 1 \\
\cline { 2 - 3 } & $70-<80$ (Perlu Perbaikan) & 2 \\
\cline { 2 - 3 } & $80-<90$ (Baik) & 3 \\
\cline { 2 - 3 } & $90-<100$ (Sangat Baik) & 4 \\
\cline { 2 - 3 } & $\geq 100$ (Istimewa) & 5 \\
\hline
\end{tabular}

\section{c. Penilaian Perilaku}

Indikator yang digunakan dalam menentukan karyawan teladan berdasarkan perilaku adalah sikap dan perilaku karyawan dalam melaksanakan setiap tugas dan kerja yang diberikan oleh perusahaan seperti yang ditunjukan dalam Tabel 3 .

Tabel 3. Kriteria Penilaian Perilaku

\begin{tabular}{|c|c|c|}
\hline \multirow{2}{*}{ Kriteria } & Range & Bobot \\
\hline \multirow{4}{*}{$\begin{array}{c}\text { Penilaian } \\
\text { Perilaku }\end{array}$} & $<40$ (Tidak Baik) & 1 \\
\cline { 2 - 3 } & $40-<60$ (Perlu Perbaikan) & 2 \\
\cline { 2 - 3 } & $60-<80$ (Baik) & 3 \\
\cline { 2 - 3 } & $80-<100$ (Sangat Baik) & 4 \\
\cline { 2 - 3 } & $\geq 100$ (Menjadi Panutan) & 5 \\
\hline
\end{tabular}

Botot Preferensi (W) setiap kriteria yang akan digunakan adalah sebagai berikut:

$\mathrm{W} 1=$ Masa Kerja (25\%) $=0,25$

$\mathrm{W} 2=$ Penilaian Kinerja $(50 \%)=0,5$

$\mathrm{W} 3=$ Penilaian Perilaku $(25 \%)=0,25$

Dalam penentuan karyawan teladan dengan metode Simple Additive weight (SAW) berdasarkan kriteria-kriteria diatas maka diperoleh data seperti dalam tabel 4. Data yang digunakan adalah data dari 51 karyawan PT ANTAM Tbk dengan maksimal kerja 5 Tahun.
Tabel 4. Nilai dari masing-masing kriteria

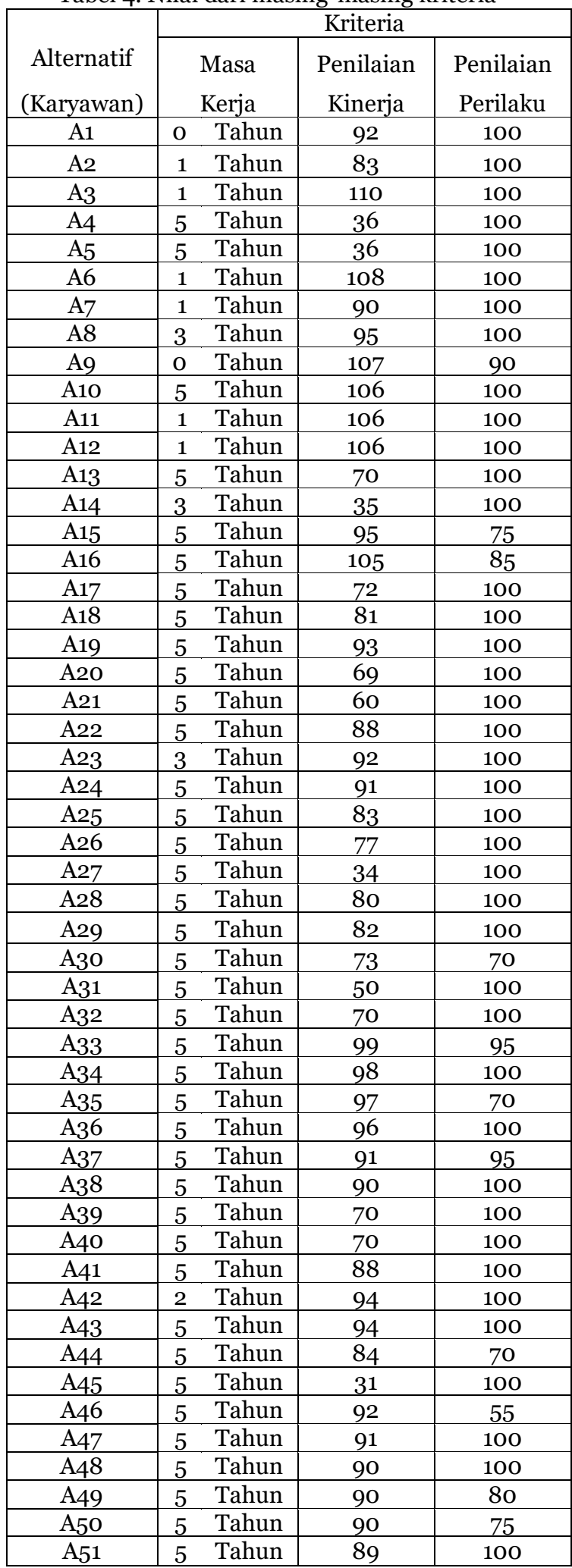

\subsection{Penentuan Rating Kecocokan Setiap Alternatif Dengan Setiap Kriteria}

Dalam penentuan rating kecocokan nilai dari masing-masing kriteria dimasukan kedalam tabel rating kecocokan yang telah disesuaikan dengan nilai dari tabel kriteria seperti yang ditunjukan dalam tabel 5 . 
Tabel 5. Rating Kecocokan

\begin{tabular}{|c|c|c|c|}
\hline \multirow{2}{*}{$\begin{array}{c}\text { Alternatif } \\
\text { (Karyawan) }\end{array}$} & \multicolumn{3}{|c|}{ Kriteria } \\
\cline { 2 - 4 } & Kerja & $\begin{array}{c}\text { Penilaian } \\
\text { Kinerja }\end{array}$ & $\begin{array}{c}\text { Penilaian } \\
\text { Perilaku }\end{array}$ \\
\hline
\end{tabular}

\begin{tabular}{|c|c|c|c|}
\hline $\mathrm{A} 1$ & 1 & 4 & 5 \\
\hline $\mathrm{A} 2$ & 1 & 3 & 5 \\
\hline $\mathrm{A} 3$ & 1 & 5 & 5 \\
\hline $\mathrm{A} 4$ & 5 & 1 & 5 \\
\hline $\mathrm{A} 5$ & 5 & 1 & 5 \\
\hline $\mathrm{A} 6$ & 1 & 5 & 5 \\
\hline
\end{tabular}

\begin{tabular}{|l|l|l|l|}
\hline A6 & 1 & 5 & 5 \\
\hline A7 & 1 & 4 & 5 \\
\hline A8 & 3 & 4 & 5 \\
\hline A9 & 1 & 5 & 4
\end{tabular}

\begin{tabular}{|c|l|l|l|}
\hline $\mathrm{A} 9$ & 1 & 5 & 4 \\
\hline $\mathrm{A} 10$ & 5 & 5 & 5 \\
\hline $\mathrm{A} 11$ & 1 & 5 & 5 \\
\hline
\end{tabular}

\begin{tabular}{|l|l|l|l|}
\hline $\mathrm{A} 12$ & 1 & 5 & 5 \\
\hline $\mathrm{A} 13$ & 5 & 2 & 5 \\
\hline $\mathrm{A} 14$ & 3 & 1 & 5 \\
\hline $\mathrm{A} 15$ & 5 & 4 & 3 \\
\hline $\mathrm{A} 16$ & 5 & 5 & 4 \\
\hline
\end{tabular}

\begin{tabular}{|l|l|l|l|}
\hline $\mathrm{A} 17$ & 5 & 5 & 4 \\
\hline $\mathrm{A} 18$ & 5 & 2 & 5 \\
\hline $\mathrm{A} 19$ & 5 & 3 & 5 \\
\hline $\mathrm{A} 20$ & 5 & 4 & 5 \\
\hline
\end{tabular}

\begin{tabular}{|l|l|l|l|}
\hline A20 & 5 & 1 & 5 \\
\hline A21 & 5 & 1 & 5 \\
\hline A22 & 5 & 3 & 5 \\
\hline
\end{tabular}

\begin{tabular}{|l|l|l|l|}
\hline A23 & 3 & 4 & 5 \\
\hline A24 & 5 & 4 & 5 \\
\hline A25 & 5 & 3 & 5 \\
\hline
\end{tabular}

\begin{tabular}{|l|l|l|l|}
\hline A25 & 5 & 3 & 5 \\
\hline A26 & 5 & 2 & 5 \\
\hline A27 & 5 & 1 & 5 \\
\hline A28 & 5 & 3 & 5 \\
\hline
\end{tabular}

\begin{tabular}{|c|c|c|c|}
\hline A28 & 5 & 3 & 5 \\
\hline A29 & 5 & 3 & 5 \\
\hline A30 & 5 & 2 & 3 \\
\hline A31 & 5 & 1 & 5 \\
\hline
\end{tabular}

\begin{tabular}{|c|c|c|c|}
\hline A32 & 5 & 2 & 5 \\
\hline A33 & 5 & 4 & 4 \\
\hline A34 & 5 & 4 & 5 \\
\hline A35 & 5 & 4 & 3 \\
\hline A36 & 5 & 4 & 5 \\
\hline
\end{tabular}

\begin{tabular}{|l|l|l|l|}
\hline A35 & 5 & 4 & 3 \\
\hline A36 & 5 & 4 & 5 \\
\hline A37 & 5 & 4 & 4 \\
\hline A38 & 5 & 4 & 5 \\
\hline A39 & 5 & 2 & 5 \\
\hline
\end{tabular}

\begin{tabular}{|c|c|c|c|}
\hline A39 & 5 & 2 & 5 \\
\hline A40 & 5 & 2 & 5 \\
\hline A41 & 5 & 3 & 5 \\
\hline A42 & 2 & 4 & 5 \\
\hline A43 & 5 & 4 & 5 \\
\hline A44 & 5 & 3 & 3 \\
\hline A45 & 5 & 1 & 5 \\
\hline A46 & 5 & 4 & 2 \\
\hline A47 & 5 & 4 & 5 \\
\hline A48 & 5 & 4 & 5 \\
\hline A49 & 5 & 4 & 4 \\
\hline A50 & 5 & 4 & 3 \\
\hline A51 & 5 & 3 & 5 \\
\hline
\end{tabular}

\subsection{Membuat Matriks Keputusan Berdasarkan Kriteria $\left(C_{i}\right)$}

Nilai dari hasil tabel kecocokan kemudian dibuat kedalam bentuk matriks yang dapat dilihat pada persamaan (7)

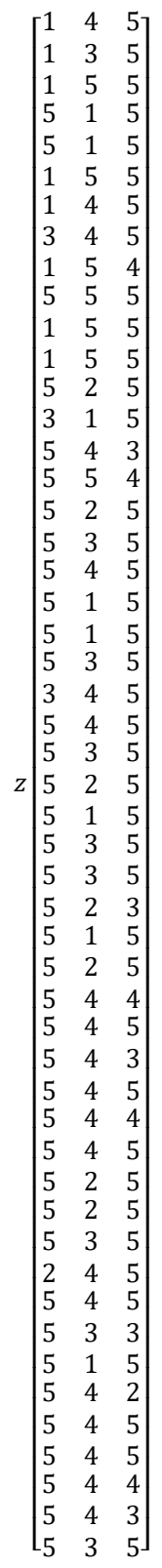

(7)

\subsection{Membuat Normalisasi Matriks}

Membuat Normalisasi Matriks berdasarkan persamaan yang disesuaikan dengan jenis atribut (atribut keuntungan maupun atribut biaya) sehingga diperoleh matriks ternormalisasi $\mathrm{R}$.

Tabel 6. Penentuan Benefit dan Cost

\begin{tabular}{|l|c|c|}
\hline \multicolumn{1}{|c|}{ Kriteria } & Benefit & Cost \\
\hline Masa Kerja & $\sqrt{ }$ & - \\
\hline Penilaian Kinerja & $\sqrt{ }$ & - \\
\hline Penilaian Perilaku & $\sqrt{ }$ & - \\
\hline
\end{tabular}

Karena semua kriteria merupakan atribut benefit maka persamaan yang digunakan adalah persamaan (4) untuk kriteria benefit.

$$
R_{i j}=\frac{X_{i j}}{\operatorname{Max}\left(X_{i j}\right)}
$$


Dari perhitungan Nilai $\mathrm{R}$ diperoleh matriks $\mathrm{R}$ yang ditunjukan dalam persamaan (8).

$\left[\begin{array}{rrr}0,2 & 0,8 & 1 \\ 0,2 & 0,6 & 1 \\ 0,2 & 1 & 1 \\ 1 & 0,2 & 1 \\ 1 & 0,2 & 1 \\ 0,2 & 1 & 1 \\ 0,2 & 0,8 & 1 \\ 0,6 & 0,8 & 1 \\ 0,2 & 1 & 0,8 \\ 1 & 1 & 1 \\ 0,2 & 1 & 1 \\ 0,2 & 1 & 1 \\ 1 & 0,4 & 1 \\ 0,6 & 0,2 & 1 \\ 1 & 0,8 & 0,6 \\ 1 & 1 & 0,8 \\ 1 & 0,4 & 1 \\ 1 & 0,6 & 1 \\ 1 & 0,8 & 1 \\ 1 & 0,2 & 1 \\ 1 & 0,2 & 1 \\ 1 & 0,6 & 1 \\ 0,6 & 0,8 & 1 \\ 1 & 0,8 & 1 \\ 1 & 0,6 & 1 \\ 1 & 0,4 & 1 \\ 1 & 0,2 & 1 \\ 1 & 0,6 & 1 \\ 1 & 0,6 & 1 \\ 1 & 0,4 & 0,6 \\ 1 & 0,2 & 1 \\ 1 & 0,4 & 1 \\ 1 & 0,8 & 0,8 \\ 1 & 0,8 & 1 \\ 1 & 0,8 & 0,6 \\ 1 & 0,8 & 1 \\ 1 & 0,8 & 0,8 \\ 1 & 0,8 & 1 \\ 1 & 0,4 & 1 \\ 1 & 0,4 & 1 \\ 1 & 0,6 & 1 \\ 0,4 & 0,8 & 1 \\ 1 & 0,8 & 1 \\ 1 & 0,6 & 0,6 \\ 1 & 0,2 & 1 \\ 1 & 0,8 & 0,4 \\ 1 & 0,8 & 1 \\ 1 & 0,8 & 1 \\ 1 & 0,8 & 0,8 \\ 1 & 0,8 & 0,6 \\ 1 & 0,6 & 1\end{array}\right]$

\subsection{Menentukan Rangking}

Untuk mencari nilai dari masing-masing karyawan yang akan mendapat penghargaan karyawan teladan, berikut proses penentuan rangking dengan perhitungan menggunakan persamaan (6).

$$
V_{i}=\sum_{j=1}^{n} W_{j} R_{i j}
$$

Menentukan nilai $V_{1}$ sampai dengan $V_{51}$ :

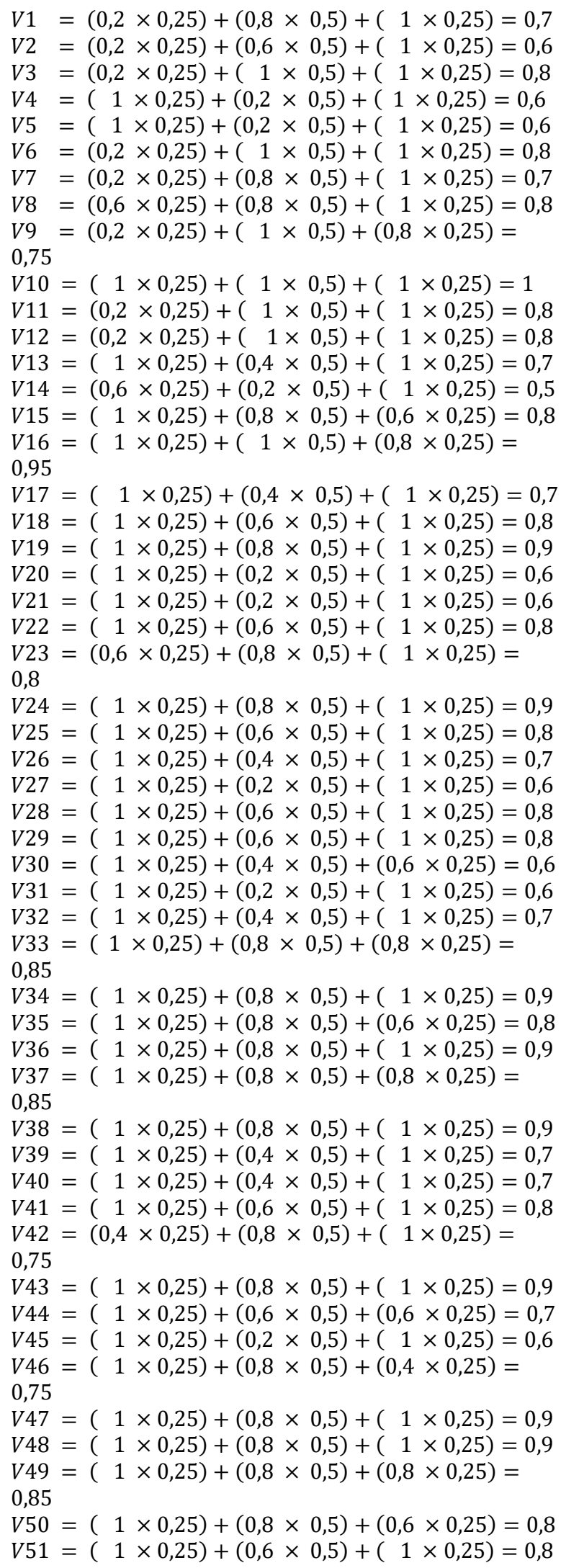

Dari hasil perhitungan nilai $V_{i}$ dari setiap karyawan yang akan mendapatkan penghargaan untuk karyawan teladan maka dapat dibuatkan tabel sesuai dengan tabel 7. 
Tabel 7. Penentuan Rangking

\begin{tabular}{|c|c|c|c|}
\hline $\begin{array}{c}\text { Alternatif } \\
\text { (Karyawan) }\end{array}$ & Nilai & $\begin{array}{c}\text { Persentase } \\
(\%)\end{array}$ & Rangking \\
\hline A10 & 1 & 100 & 1 \\
\hline A16 & 0.95 & 95 & 2 \\
\hline A19 & 0.9 & 90 & 3 \\
\hline A24 & 0.9 & 90 & 4 \\
\hline A34 & 0.9 & 90 & 5 \\
\hline A36 & 0.9 & 90 & 6 \\
\hline A38 & 0.9 & 90 & 7 \\
\hline A43 & 0.9 & 90 & 8 \\
\hline A47 & 0.9 & 90 & 9 \\
\hline A48 & 0.9 & 90 & 10 \\
\hline A33 & 0.85 & 85 & 11 \\
\hline A37 & 0.85 & 85 & 12 \\
\hline A49 & 0.85 & 85 & 13 \\
\hline A3 & 0.8 & 80 & 14 \\
\hline A6 & 0.8 & 80 & 15 \\
\hline A8 & 0.8 & 80 & 16 \\
\hline A11 & 0.8 & 80 & 17 \\
\hline A12 & 0.8 & 80 & 18 \\
\hline $\mathrm{A} 15$ & 0.8 & 80 & 19 \\
\hline A18 & 0.8 & 80 & 20 \\
\hline A22 & 0.8 & 80 & 21 \\
\hline A23 & 0.8 & 80 & 22 \\
\hline A25 & 0.8 & 80 & 23 \\
\hline A28 & 0.8 & 80 & 24 \\
\hline A29 & 0.8 & 80 & 25 \\
\hline A35 & 0.8 & 80 & 26 \\
\hline A41 & 0.8 & 80 & 27 \\
\hline A50 & 0.8 & 80 & 28 \\
\hline A51 & 0.8 & 80 & 29 \\
\hline A9 & 0.75 & 75 & 30 \\
\hline A42 & 0.75 & 75 & 31 \\
\hline A46 & 0.75 & 75 & 32 \\
\hline A1 & 0.7 & 70 & 33 \\
\hline A7 & 0.7 & 70 & 34 \\
\hline $\mathrm{A} 13$ & 0.7 & 70 & 35 \\
\hline A17 & 0.7 & 70 & 36 \\
\hline A26 & 0.7 & 70 & 37 \\
\hline A32 & 0.7 & 70 & 38 \\
\hline A39 & 0.7 & 70 & 39 \\
\hline A40 & 0.7 & 70 & 40 \\
\hline A44 & 0.7 & 70 & 41 \\
\hline A2 & 0.6 & 60 & 42 \\
\hline $\mathrm{A} 4$ & 0.6 & 60 & 43 \\
\hline $\mathrm{A} 5$ & 0.6 & 60 & 44 \\
\hline A2O & 0.6 & 60 & 45 \\
\hline A21 & 0.6 & 60 & 46 \\
\hline A27 & 0.6 & 60 & 47 \\
\hline A30 & 0.6 & 60 & 48 \\
\hline A31 & 0.6 & 60 & 49 \\
\hline A45 & 0.6 & 60 & 50 \\
\hline A14 & 0.5 & 50 & 51 \\
\hline
\end{tabular}

Dari penentuan karyawan teladan dengan menggunakan metode Simple Additive Weight (SAW), maka yang layak menjadi karyawan teladan adalah karyawan pada Alternatif ke 10 (A10) dengan nilai 100 yang dilihat pada Tabel 7 .

\subsection{Desain User Interface}

Desain User Interface pada Sistem Pendukung Keputusan Pemilihan Karyawan Teladan di PT ANTAM Tbk Unit Bisnis Pertambangan Buli menggunakan metode Simple Additive Weight (SAW) seperti Gambar 2.

1) Halaman login

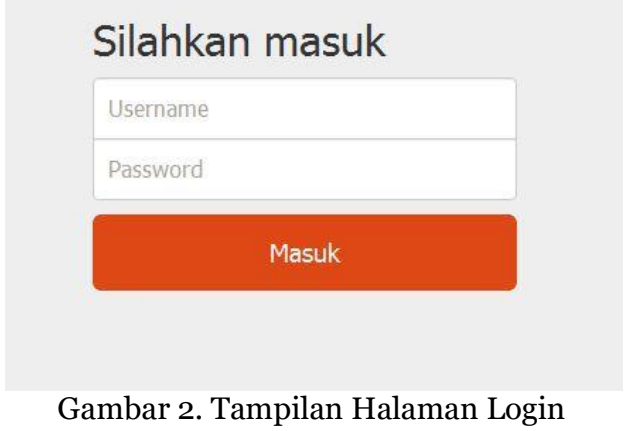

Gambar 2 adalah rancangan user interface untuk Halaman Login Sistem Pendukung Keputusan Pemilihan Karyawan Teladan di PT ANTAM Tbk Unit Bisnis Pertambangan Buli.

2) Halaman Utama

Setelah Admin melakukan login maka sistem akan masuk ke halaman utama. Desain Halaman Utama ditampilkan pada Gambar 3.

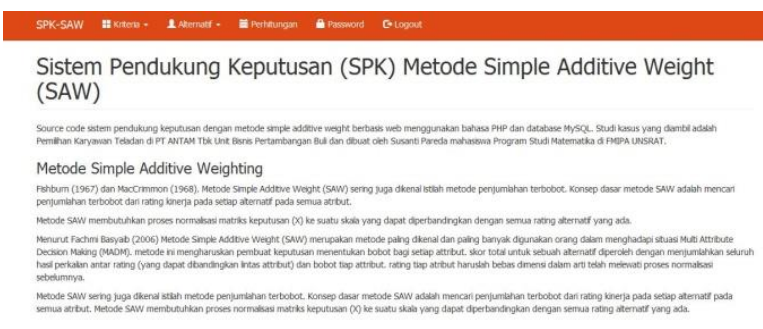

Gambar 3. Tampilan Halaman Utama

3) Halaman Menu Kriteria

Pada menu kriteria terdapar 2 submenu yaitu Kriteria dan Indikator Penilaian. Pada menu kriteria menampilkan tentang kriteria yang digunakan, atribut setiap kriteria dan bobot setiap kriteria dan dilengkapi fasilitas pencarian, refresh, tambah, cetak, edit dan hapus. Sedangkan untuk Indikator Penilaian menampilkan kriteria, range dan nilai bobot dan dilengkapi dengan fasilitas pencarian, refresh, tambah, edit dan hapus. Desain halaman kriteria ditampilkan pada Gambar 4 dan Gambar 5 .

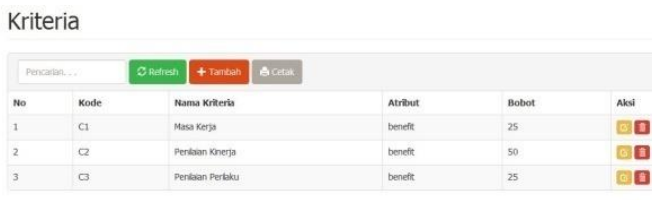

Gambar 4. Tampilan Halaman Kriteria 


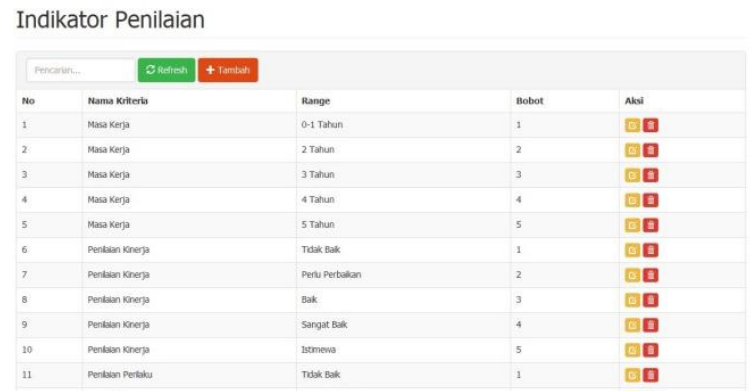

Gambar 5. Tampilan Halaman Indikator Penilaian

4) Halaman Menu Alternatif

Pada menu alternatif terdapar 2 submenu yaitu Alternatif dan Nilai Alternatif. Pada menu alternatif menampilkan data dari alternatif berupa kode/Nomor id, Nama Alternatif serta keterangan dari setiap alternatif dan dilengkapi fasilitas pencarian, refresh, tambah, cetak, edit dan hapus. Sedangkan untuk Nilai Alternatif menampilkan nilai bobot setiap alternatif untuk setiap kriteria dan dilengkapi dengan fasilitas pencarian dan ubah, Desain halaman Alternatif ditampilkan pada Gambar 6 dan Gambar 7.

Alternatif
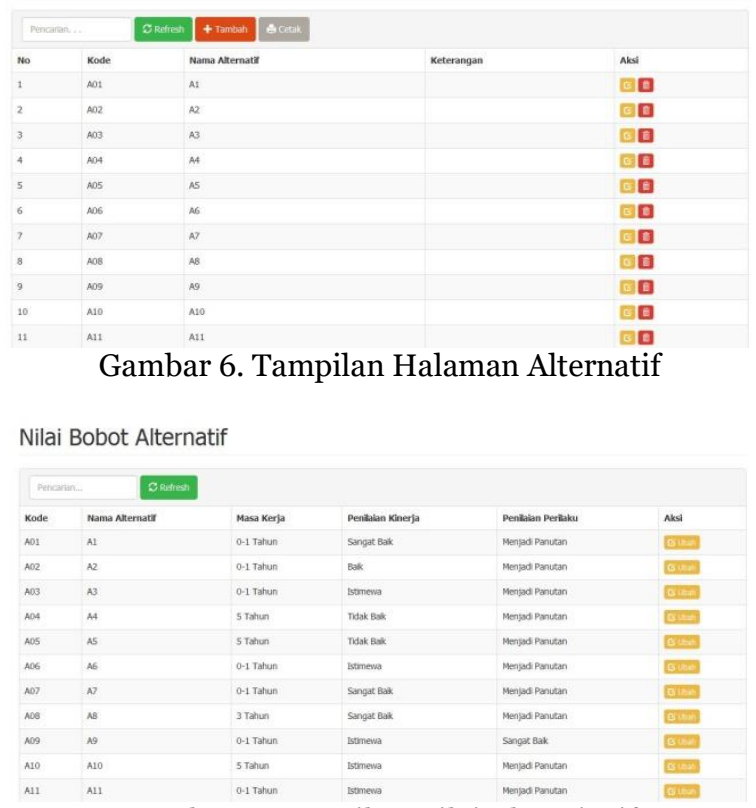

Gambar 7. Tampilan Nilai Altern `atif

5) Halaman Perhitungan

Pada Halaman perhitungan menampilkan hasil analisa dari alternatif untuk setiap kriteria, normalisasi dan perangkingan yang merupakan hasil dari perhitungan menggunakan metode Simple Additive Weight (SAW), halaman ini juga dilengkapi dengan fasilitas cetak. Desain Halaman Perhitungan akan ditampilkan pada Gambar 8, Gambar 9 dan Gambar 10 .

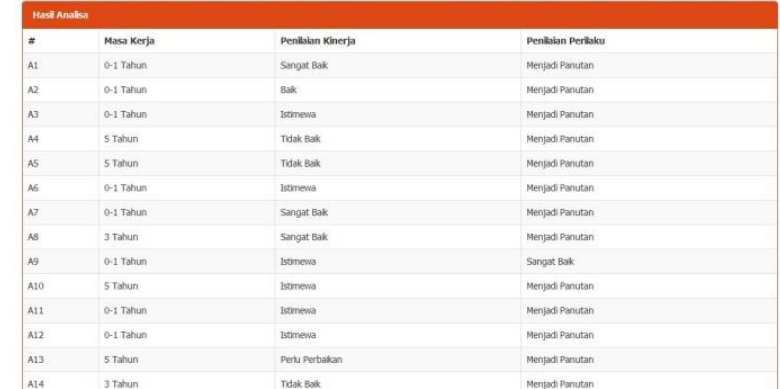

Gambar 8. Tampilan Hasil Analisa Perhitungan

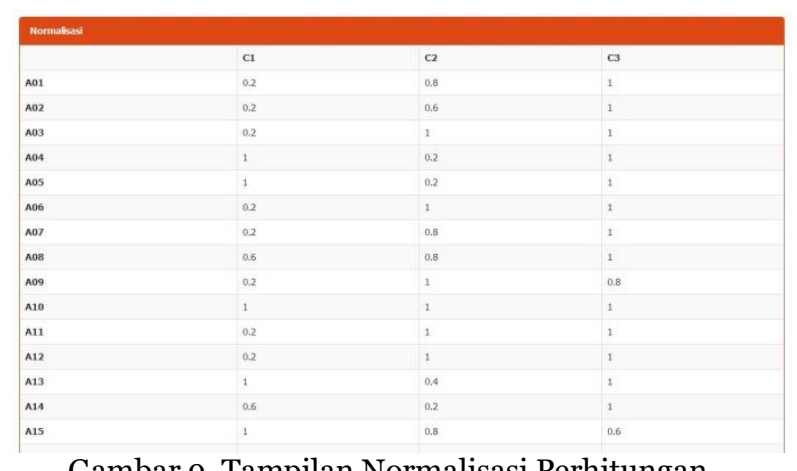

Gambar 9. Tampilan Normalisasi Perhitungan

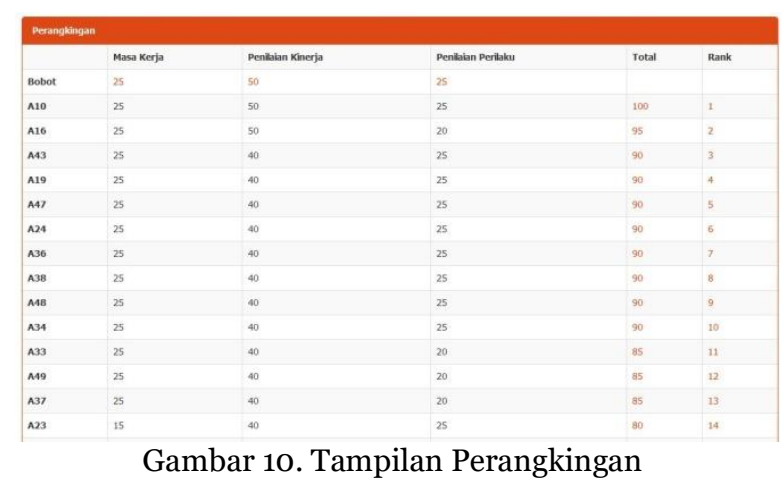

Berdasarkan penentuan rangking pada Tabel 7 dan Gambar 10 dapat dilihat bahwa A10 menempati tempat pertama untuk rekomendasi karyawan teladan di PT ANTAM Tbk dengan persentasi nilai 100\%, pada Tabel 4 dapat dilihat bahwa hal ini dikarenakan A1o memiliki nilai bobot tertinggi untuk setiap kriteria, A10 merupakan karyawan telah bekerja di PT ANTAM Tbk selama 5 Tahun, karyawan A10 juga mendapat nilai tertinggi dari Kepala Biro tempat A1o ditempatkan untuk bekerja yaitu 106, dan memiliki nilai 100 dalam hal berperilaku yang artinya A1o tidak perna melakukan pelanggaran disiplin selama bekerja di PT ANTAM Tbk dan memiliki sikap yang baik selama bekerja.

Untuk peringkat ke 2 ditempati oleh A16 dengan persentasi nilai $95 \%$ yang hanya berbeda $5 \%$ dari A10 hal ini dikarenakan A16 mendapat nilai 85 dalam penilaian perilaku, hal ini menjelaskan bahwa lama bekerja, dan kinerja yang baik harus pula di imbangi dengan perilaku yang baik karena perilaku yang buruk dapat berpengaruh pada produktivitas perusahaan. Selanjutnya untuk peringkat 3 sampai dengan 10 dapat dilihat pada Tabel 7 dan Gambar 10 memiliki urutan yang berbeda hal itu dikarenakan karyawan A19, A24, A34, A36, A38, A43, A47 dan A48 memiliki nilai hasil yang sama yaitu $90 \%$ sehingga 
perangkingannya dapat diurutkan berdasarkan dengan kebutuhan perusahaan.

Pada Tabel 7 juga dapat dilihat bahwa karyawan A3, A6, A17 dan A18 merupakan karyawan dengan masa kerja 1 tahun dan memiliki bobot terendah namun mendapat peringkat lebih tinggi dibandingkan dengan 27 karyawan lainnya dengan masa kerja 5 tahun yang memiliki bobot tertinggi pada kriteria masa kerja. Hal ini dikarenakan karyawan A3, A6, A17 dan A18 memiliki nilai yang tinggi pada penilaian kinerja dan perilaku yang dapat dilihat pada tabel 4 . Hal ini menegaskan bahwa untuk memilih karyawan teladan tidak selamanya dapat dilihat dari seberapa lama karyawan sudah bekerja di perusahaan, namun hal yang penting adalah seberapa baik kinerja karyawan selama bekerja diperusahaan. Contoh lainnya juga dapat dilihat pada Tabel 7 yaitu karyawan A20 san A21 yang merupakan karyawan yang sudah bekerja selama 5 Tahun namun memiliki penilaian kinerja yang sangat rendah disbanding dengan karyawan lain yang memiliki masa kerja 5 Tahun dengan bobot yang didapatkan adalah bobot terendah yaitu 1 sehingga karyawan A20 dan A21 mendapat peringkat ke 45 dan 46 dari 51 karyawan, hal ini menegaskan pentingnya kinerja karyawan dalam pemilihan karyawan teladan.

Pada Tabel 7 dan Gambar 10 juga memperlihatkan bahwa A6 dan A8 menempati peringkat ke 15 dan 16 dengan nilai yang sama yaitu 80, A6 dan A8 memiliki masa kerja yang berbeda yaitu A6 masa kerjanya 1 Tahun dan A8 masa kerjanya 3 Tahun namun mereka tetap memiliki hasil yang sama. A8 memiliki nilai masa kerja yang tinggi namun memiliki nilai kinerja yang lebih rendah dari A6 yaitu 95 banding 108 hal ini juga memperjelas bahwa penentuan bobot preferensi sangatlah penting guna mendapatkan hasil yang baik sesuai dengan kebutuhan perusahaan. Hasil dari pernelitian ini tidak hanya untuk menentukan karyawan teladan pada PT ANTAM Tbk namun dapat juga menjadi bahan acuan untuk melihat karyawan yang perlu untuk dievaluasi kinerjanya oleh SDM perusahaan.

\section{Penutup}

\subsection{Kesimpulan}

1. Sistem Pendukung Keputusan Pemilihan Karyawan Teladan berbasis Web telah berhasil di rancang dengan menggunakan bahasa pemrograman PHP dan database MySQL.

2. Dari perhitungan dengan menggunakan metode Simple Additive Weigth (SAW), dengan acuan kriteria masa kerja, penilaian kinerja, dan penilaian perilaku karyawan maka terpilih seorang karyawan yang akan mendapatkan sertifikat karyawan teladan di PT ANTAM Tbk yaitu karyawan A1o dengan persentase nilai 100\%. Dan dari hasil analisis perhitungan semua alternatif didapati kesimpulan bahwa untuk menjadi karyawan teladan tidak hanya dilihat dari seberapa lama karyawan tersebut bekerja tetapi juga harus memiliki kinerja dan perilaku yang baik.

\subsection{Saran}

1. Perlu dilakukan pemeliharaan dan pengawasan dari pihak yang bertanggung jawab terhadap sistem.

2. Memilih seorang Administrator yang terlatih, jujur dan bertanggung jawab baik dalam penggunaan maupun pemeliharaan program aplikasi

\section{REFERENSI}

[1] Anisyah. (2009). Analisa dan Desain Sistem Informasi. Yogyakarta: ANDI.

[2] Fithri, D. L., \& Latifah, N. (2012). Sistem Pendukung Keputusan Untuk Pemberian Bantuan Usaha Mikro Dengan Metode Simple Additive Weighting. Majalah Ilmiah Informatika, 3(2): 117-129.

[3] Ontah G.M., W. Weku., \& A. J. Rindengan. (2014). Sistem Pendukung Keputusan Dalam Memetakan Wilayah Risiko Banjir Menggunakan Fuzzy Multi Criteria Decision Making. Jurnal d'Cartesian, 3(2): 1-30.

[4] Kadir, A. (2003). Pengenalan Sistem Informasi. Yogyakarta: ANDI.

[5] Nofriansyah. (2014). Konsep Data Mining Vs Sistem Pendukung Keputusan. Yogyakarta: Deepublish.

[6] Nugroho, Bunafit. (2009). Database Relation dengan MySQL. Yogyakarta: ANDI.

[7] PT ANTAM Tbk. 2014. www.antam.com. [25 mei 2018]

[8] Sulistianingsih, N., Kusumadewi, S., \& Kariyam. (2015). Analysis of Dialogue Technique Acceptance of Diagnosis Based Clinical Decision Support System. Jurnal Ilmiah Kursor, 8(1):1-12.

[9] Sutarman. (2004). Dasar Pemrograman Web Dinamis menggunakan PHP. Yogyakarta: ANDI.

Susanti Pareda (susan.pareda@gmail.com)

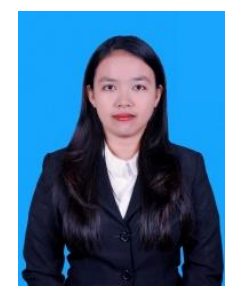
Lahir di Desa Buli, Kabupaten Halmahera Timur Provinsi Maluku Utara pada tanggal 13 Juli 1995. Menempuh pendidikan tinggi Jurusan Matematika, FMIPA, Universitas Sam Ratulangi Manado. Tahun 2018 adalah tahun terakhir ia menempuh studi. Makalah ini merupakan hasil penelitian skripsinya yang dipublikasikan.

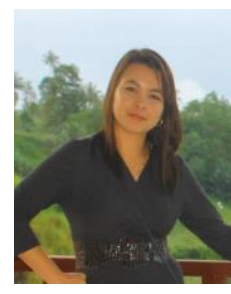

Chriestie E.J.C Montolalu (Chriestelly@unsrat.ac.id)

Lahir pada tanggal 10 Desember 1985. Pada tahun 2007 mendapatkan gelar Sarjana Sains (S.Si) yang diperoleh dari Universitas Sam Ratulangi Manado. Gelar Master Of Science (M.Sc) 
diperoleh dari Universitas Of Queensland Australia pada tahun 2015. Ia bekerja di UNSRAT di Program Studi Matematika sebagai pengajar akademik tetap UNSRAT.

\section{Charles E. Mongi ( charlesmongi@unsrat.ac.id )}

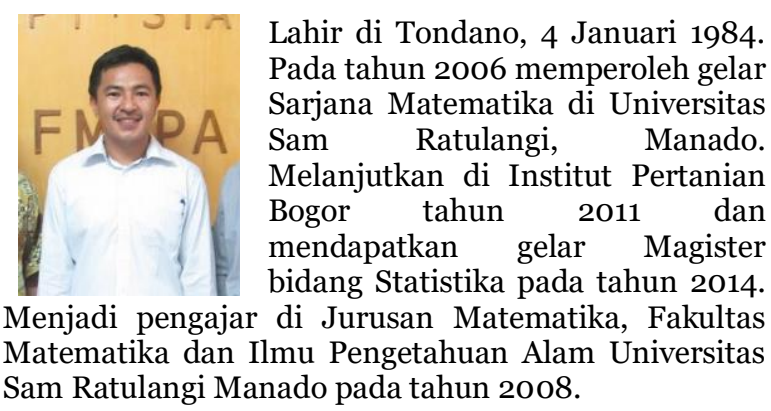

